\title{
IMPLEMENTASI LOAD BALANCING DENGAN METODE BUBBLE SORT STUDI KASUS PENGISIAN KRS DI STTA
}

\author{
Rahmad Hidayad, Agus Basukesti, Yuliani Indrianingsih \\ Jurusan Teknik Informatika \\ Sekolah Tinggi Teknologi Adisutjipto Yogyakarta \\ informatika@stta.ac.id
}

\begin{abstract}
The increase of request brings large traffic to networks especially to data centers, large enterprises and portal websites. In addition, server provides more and more information by using applications. Most servers have to provide all-day services, and any service interruption or key data loss in communication will result in business loss. All these require high performance and high reliability on application services. However, the increase of server processing speed and memory access speed is greatly lower than that of the network bandwidth and applications. In addition, the increase of network bandwidth makes server resource consumption more serious. Therefore, the servers become the network bottleneck, and the traditional single device mode becomes the network failure point. Load balancing (LB) comes to provide a good solution by providing multiple servers form a server cluster, with each server providing the same or similar services. A load balancing application is managed at the front end of the server cluster to distribute user requests in the server cluster according to pre-configured load balancing rules, provide services, and maintain the servers. Load balancing bring good advantage such as bring faster application, low cost, the available resources will not be wasted, and no high-end devices are needed for the new resources. It is expandability. When services are increasing, the system can satisfy the needs by adding servers, without affecting the existing services and reducing service quality. Load balancing also has high reliability. When a server fails, the LB application or LB device redistributes user requests to other servers in the same cluster, ensuring uninterrupted services.
\end{abstract}

Keywords: load balancing, synchronization, server.

\section{Pendahuluan}

Dari tahun ke tahun STTA (Sekolah Tinggi Teknologi Adisutjipto) mengalami perkembangan, terutama dalam kebutuhan akan layanan informasi. Kebutuhan akan sistem informasi penunjang kegiatan perkuliahan perlu ditingkatkan seiring pertambahan mahasiswa.

Sistem Akademik di STTA menggunakan database terpusat menggunakan aplikasi Postgres. Aplikasi Postgres sendiri memiliki banyak keterbatasan, salah satunya adalah kemampuan dalam menangani permintaan dari client. Oleh karena itu perlu dibuat sebuah sistem yang dapat meningkatkan kinerja server dalam menangani permintaan layanan dari client. Salah satu cara adalah dengan menerapkan sistem terdistribusi dengan membagi beban layanan server database.

Model yang dibuat adalah dengan menggunakan database terpisah yang berfungsi sebagai temporary database yang melayani permintaan client. Data hasil pemrosesan yang valid akan tersimpan pada server utama. Proses load balancing terjadi dengan mengalihkan request layanan dari client kepada server yang memiliki lebih sedikit proses yang sedang ditangani. 
Efek yang dihasilkan adalah beban server utama menjadi lebih ringan karena beban juga terdistribusi ke temporary server. Sebagai implementasinya adalah dengan menerapkan model tersebut pada sistem pengisian KRS dimana server database mendapatkan request layanan dalam jumlah besar oleh banyaknya client yang mengakses dalam kurun waktu tertentu (masa pengisian krs).

Sistem informasi yang memanfaatkan jaringan komputer sering mengalami masalah dalam hal pemanfaatan resource yang merujuk pada performa layanan, waktu pemrosesan layanan, maupun ketersediaan layanan itu sendiri. Load balancing digunakan untuk menyelesaikan permasalahan tersebut dengan menyeimbangkan permintaan layanan antara beberapa server. Load balancing dilakukan dengan menggunakan pelbagai aturan tergantung jenis layanan, hardware, dan pengaturan oleh administrator sistem.

\section{Landasan Teori}

\section{Load Balancing}

Server load balancing memiliki banyak pengertian. Dalam pustaka milik Microsoft load balancing adalah teknologi clustering yang memperbaiki skalabilitas dan ketersediaan layanan. Untuk menjamin ketersediaan layanan dilakukan pengecekan apakah ada kegagalan pada host tertentu, jika ditemukan maka akan mendistribusikan kembali traffic pada host yang masih berfungsi. Penjelasan lain didapat dari paper yang diterbitkan oleh Hewlett Packard dimana latar belakang penggunaan teknologi load balancing adalah peningkatan layanan yang mempengaruhi traffic jaringan terutama pada data center. Pada jaringan skala besar seperti pada perusahaan besar, layanan seperti HTTP, FTP, SMTP harus tersedia sepanjang waktu dan adanya interupsi pada servis atau putusnya komunikasi akan merugikan sisi bisnis, sehingga diperlukan layanan yang memiliki performa tinggi dan dapat tersedia setiap waktu. Saat itu peningkatan kecepatan server dan kecepatan akses memory lebih rendah dibanding peningkatan network bandtwidth, sehingga peningkatan bandwidth jaringan dapat menyebabkan jaringan bottleneck.

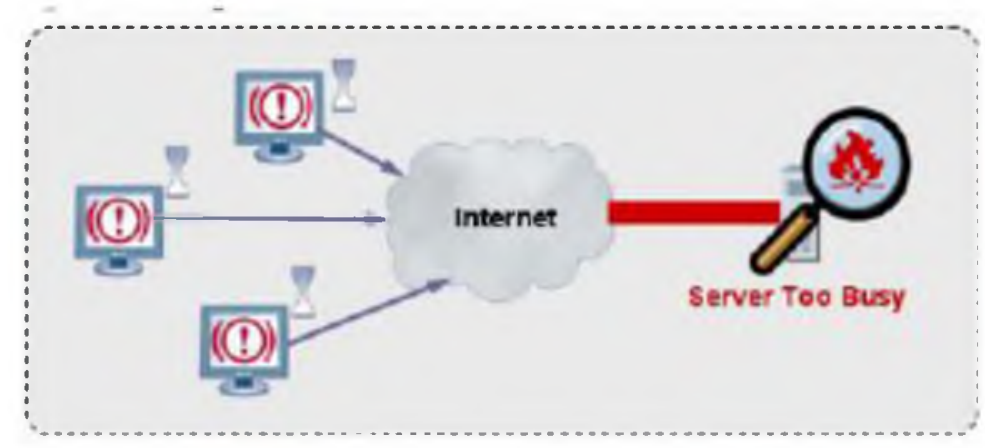

Gambar 1 Server Tidak Merespon

Gambar 1 menunjukan sistem dengan single server memungkinkan kegagalan dalam memberikan layanan. Untuk mengatasinya dibangun sistem cluster server untuk menyeimbangkan beban diantara server dengan teknologi load balancing. Multiple server membentuk cluster server yang menyediakan layanan yang sama. Load balancing device (LB 
device) ditempatkan pada front end cluster untuk mendistribusikan request user pada server menurut aturan tertentu. Skema load balancing ditunjukan pada gambar 2.

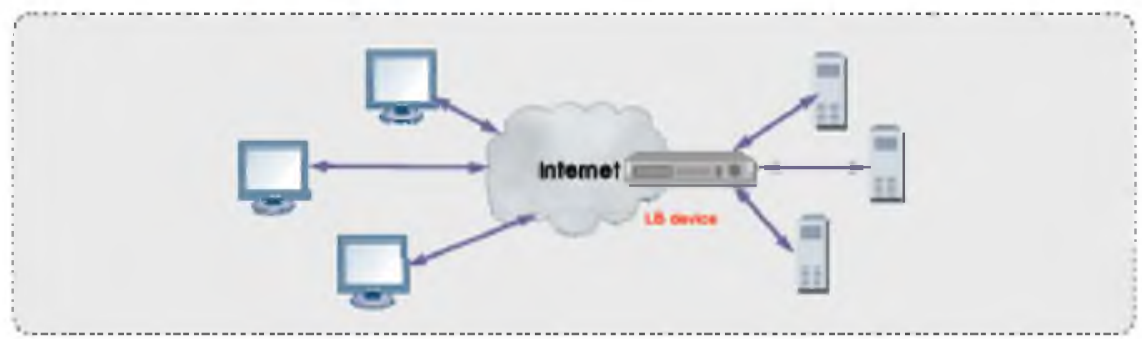

Gambar 2 Skema Load Balancing

Pengertian lain load balancing adalah definisi dari proses dan teknologi yang mendistribusikan beban komputasi jaringan ke beberapa server dengan memanfaatkan peralatan jaringan. Lalu lintas jaringan akan diarahkan ke server yang ditentukan. Proses load balancing bersifat transparan terhadap end user.

Load balancing menerapkan beberapa fungsi diantaranya:

1. Melakukan intercept lalu lintas jaringan ( misal lalulintas web ).

2. Melakukan pembagian traffic jaringan tiap-tiap request dan memutuskan server mana yang akan memberi respon layanan.

3. Mengawasi kinerja server dan memastikan server-server tersebut memberikan tanggapan setiap request. Jika tidak maka server tersebut tidak dilibatkan dalam sistem.

4. Memberikan keunggulan dengan menggunakan lebih dari satu server serta menghindari kegagalan dalam memberikan layanan server.

\section{Metode Bubble Sort}

Metode bubble sort adalah salah satu metode yang digunakan untuk mengurutkan data. Untuk mengurutkan data dilakukan proses pembandingan semua elemen data. Jika terdapat $\mathrm{N}$ data dan data terkoleksi dari urutan 0 sampai dengan $\mathrm{N}-1$ maka algoritma pengurutan dengan metode bubble sort adalah sebagai berikut:

1. Bandingkan posisi data $\mathrm{i}=0$ dan $\mathrm{j}=1$.

2. Jika data di posisi i lebih besar daripada data di posisi j, maka data di posisi i di tukar dengan data diposisi $\mathrm{j}$ (swap).

3. Kemudian, lakukan perbandingan data di posisi $i=1$ dan data di posisi $j=2$. Lakukan langkah 2, begitu juga untuk data berikutnya hingga $i=\mathrm{N}-2$ dan $j=\mathrm{N}-1$.

4. Ulangi langkah 1, 2 dan 3 untuk data diposisi 0 sampai dengan data di posisi N-2. Untuk tahap selanjutnya data yang dibandingkan akan semakin berkurang sebab data dengan nilai yang lebih besar akan terposisi di bagian sebelah kanan data.

\section{Perancangan Sistem}

\section{Perancangana Konsep Jaringan}

Salah satu persiapan dalam membangun sistem ini adalah menyiapkan konsep arsitektur jaringan. Penjelasan konfigurasi jaringan terdapat pada gambar 3. 


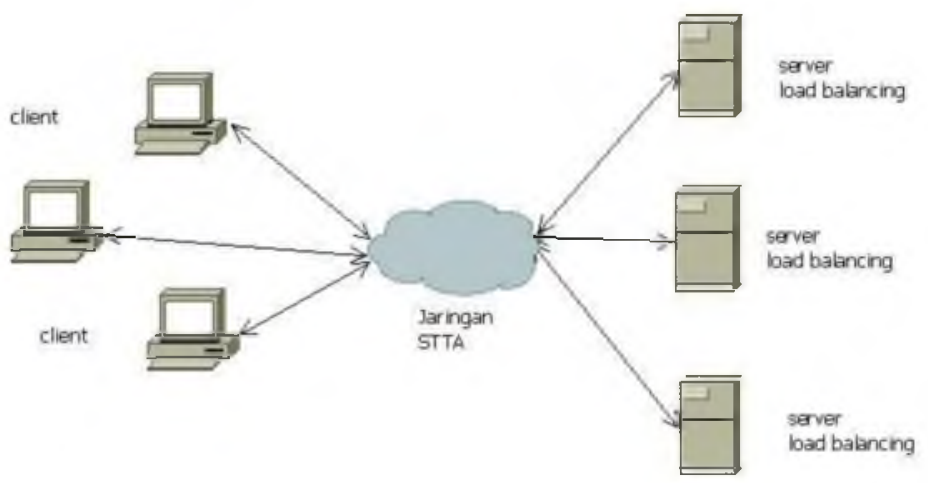

Gambar 3 Rancangan Jaringan Load Balancing

Gambar 3 merupakan konfigurasi jaringan dengan temporary database terpisah dari client. Sedangkan untuk model jaringan dengan temporary database terletak di sisi user seperti pada gambar 4

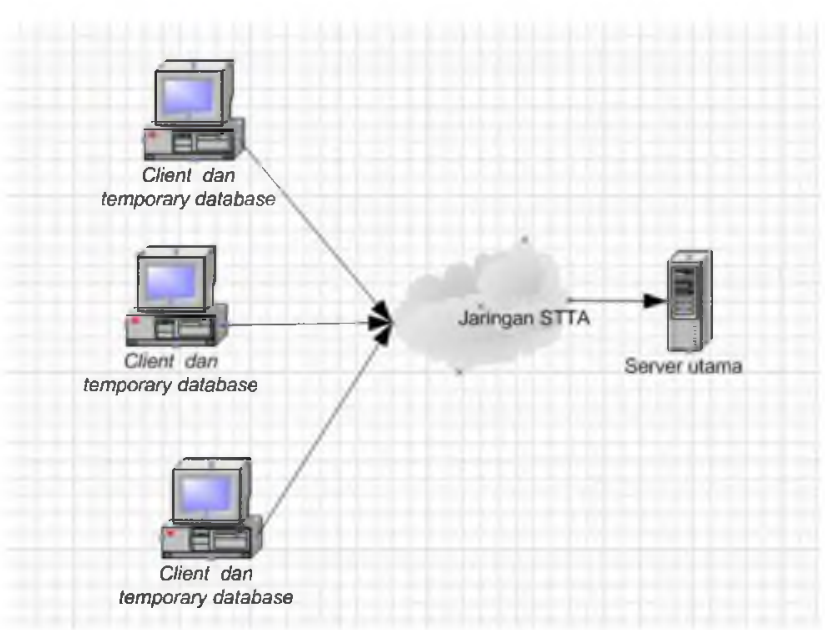

Gambar 4 Rancangan Dengan Temporary Database Di Client

\section{Perancangan Database}

Sistem pengisian KRS ini menggunakan database dari sistem pengisian KRS yang lama. Penjelasan tabel dan relasinya terdapat pada gambar 5. Pada sistem pengisian KRS terdapat dua hal yang utama yaitu pengaturan koneksi database, dan pengisian KRS itu sendiri. Pengaturan koneksi menggunakan dua koneksi, yaitu koneksi ke server utama, dan koneksi ke temporary server. Pada sistem ini terdapat beberapa proses query yang ditangani oleh temporary server dan sebagian lagi ditangani oleh server utama. Beberapa query yang ditangani oleh server utama adalah pengambilan data matakuliah, dan pengambilan data KRS semester yang lalu. Sementara query yang ditangani oleh temporary server adalah pengisian KRS dan detail matakuliahnya. 


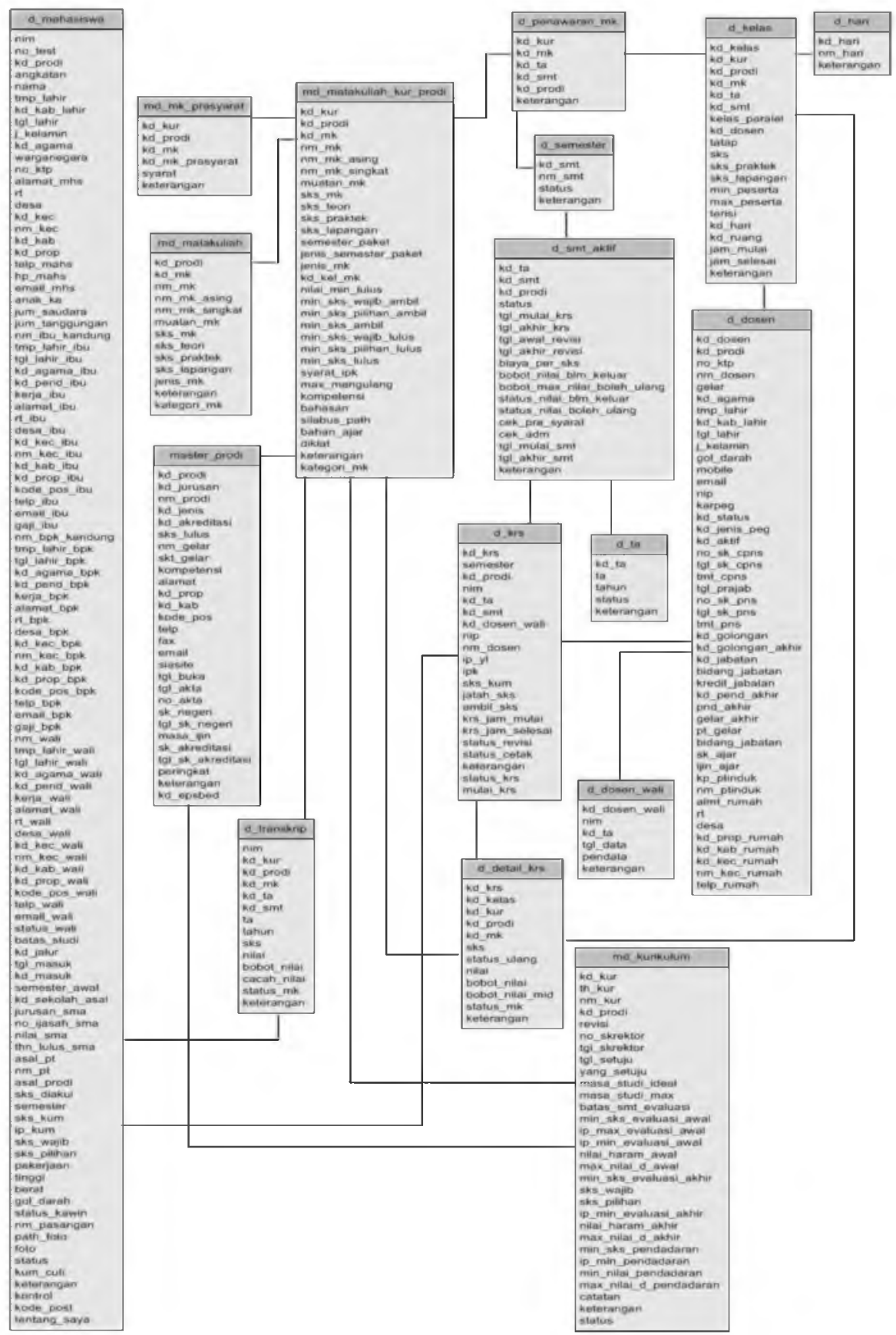

Gambar 5 Rancangan Tabel Sistem Pengisian KRS

\section{Perancangan Aplikasi Pengisian KRS}

Proses pengisian KRS dimulai saat mahasiswa login, kemudian memilih menu pengisian KRS. Proses re-direct terjadi saat user memilih menu pengisian KRS. User akan diarahkan ke server yang sudah ditentukan oleh program, kemudian daftar matakuliah akan ditampilkan. User kemudian memilih dan men-submit data matakuliah yang dipilih. Data KRS tersimpan di server bersangkutan selama masa KRS. Data KRS akan dikirim ke server utama setelah masa pengisian KRS berakhir. Flowcart dari menu utama sistem pengisian KRS adalah pada gambar 6. 


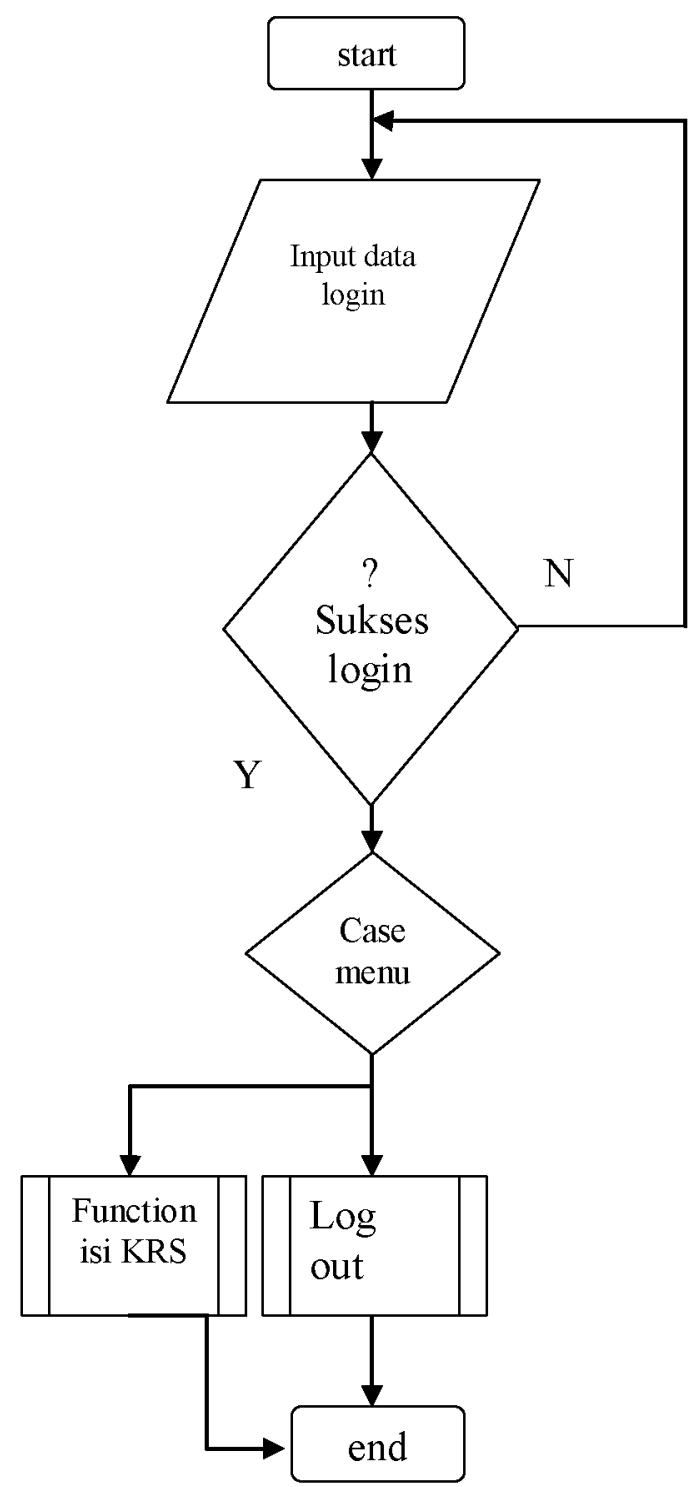

Gambar 6 Flowcart Menu Utama Pengisian KRS

Di dalam menu utama pengisian KRS terdapat submenu isi KRS. Gambar 7 menjelaskan function isi KRS yang digunakan apabila menggunakan model temporary database pada server terpisah. Sedangkan untuk model temporary database terletak pada sisi client tidak membutuhkan proses pengecekan kondisi server, daftar matakuliah langsung ditampilkan, dan data KRS langsung disimpan pada database di client masing-masing. 


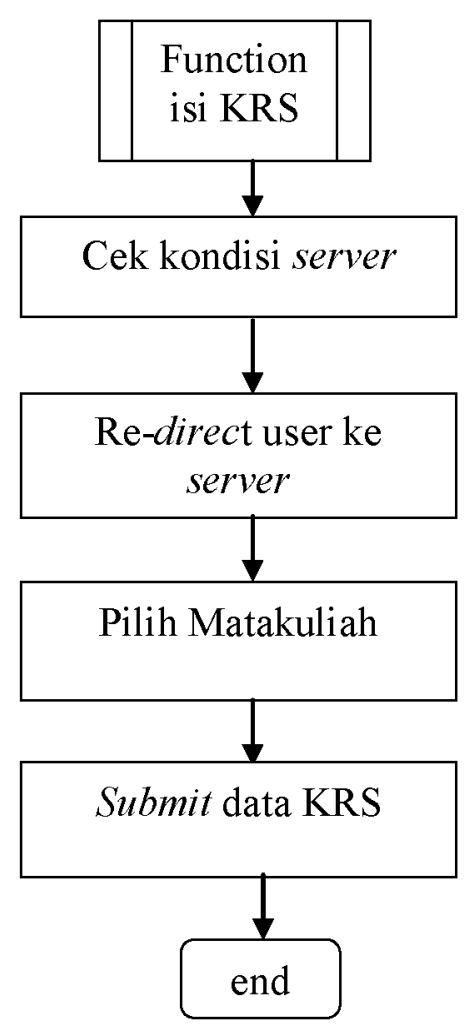

Gambar 7 Flowcart Function Isi KRS

\section{Perancangan Sinkronisasi Database}

Dalam perancangan sistem ini dibutuhkan alur diagram alir atau flow chart yang menjelaskan bagaimana alur logika program bekerja dari awal sampai akhir. Antara lain yaitu flow chart untuk proses load balancing, proses transfer data dari temporary server ke server utama, penyimpanan informasi server yang terlibat dalama proses load balancing dan pengisian KRS. Keseluruhan proses tersebut terdapat pada menu Admin.

\section{Perancangan Load Balancing}

Program yang digunakan untuk menerapkan konsep load load balancing menggunakan tabel untuk menyimpan konfigurasi server yang terlibat dalam proses load balancing. Data yang disimpan adalah data untuk koneksi ke database server temporary yaitu alamat IP, username, password, port. Flowcart proses penentuan server untuk pengisian KRS dijelaskan pada gambar 8. Algoritma ini digunakan apabila temporary database terletak pada server terpisah. 


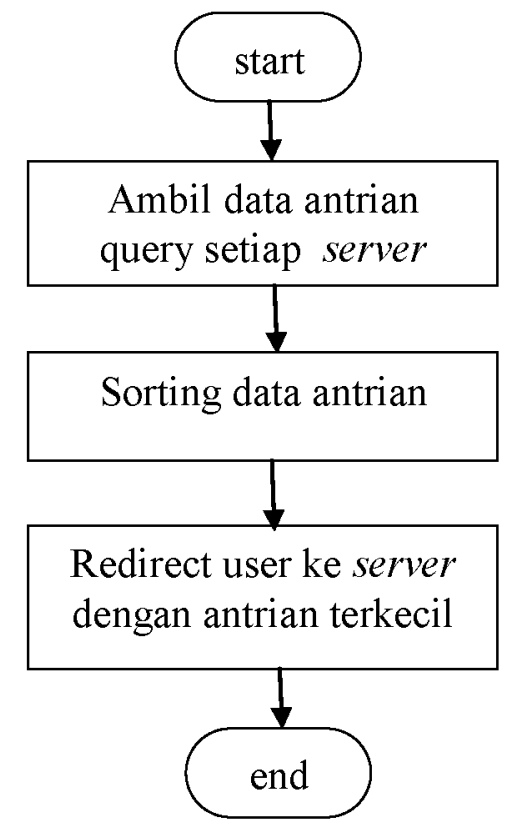

Gambar 8 Proses Pemilihan Server KRS

\section{Implementasi Dan Pembahasan}

Program pengisian KRS dengan load balancing ini ditujukan untuk meningkatkan performa sistem yang memanfaatkan layanan database. Penurunan performa layanan suatu server terjadi jika server tidak mampu menangani request dalam jumlah besar. Efek yang terjadi adalah terjadi antrian dari user, mengakibatkan proses menjadi lama.

Setiap server memiliki batasan dalam jumlah request yang bisa ditangani. Hal tersebut dipengaruhi dari kemampuan aplikasi database itu sendiri dan juga hardware yang digunakan. Aplikasi database hanya bisa memproses satu query dalam satu waktu. Sebelum melakukan proses query, aplikasi client terlebih dahulu membangun koneksi dengan server database. Data koneksi tersimpan dalam tabel pg_stat_activity. Jika tidak terjadi request berupa query, koneksi akan memiliki status idle. Jika beberapa koneksi melakukan proses query, maka akan dilakukan proses antrian menurut urutan waktu. Permintaan query yang lebih dulu masuk akan diproses lebih awal.

Program dengan load balancing ini menggunakan parameter jumlah koneksi untuk menentukan server mana yang akan menangani request dari client. Data hasil pengecekan tiap server akan ditampung dalam sebuah variable array untuk kemudian diurutkan.

\section{Tes Pengisian KRS}

Pengujian ini digunakan untuk mengetahui apakah program pengisian KRS dapat bekerja dengan baik. Hal lain yang dipertimbangkan dalam pengujian ini adalah kecepatan dalam proses pengisian KRS, serta untuk mengetahui apakah ada tidaknya kendala dalam menjalankan sistem. Ujicoba terdiri dari dilakukan dengan temporary database terpisah. Selanjutnya akan diambil kesimpulan dari kedua pengujian tersebut. 
Tes pengisian KRS dengan LAN dilakukan pada jaringan lokal di lab inherent STTA. Dari hasil pengujian KRS dengan sistem temporary database terpisah diperoleh data berikut:

Tabel 1 Hasil uji coba KRS dengan load balancing

\begin{tabular}{|c|c|c|}
\hline No & Jumlah User & Waktu rata-rata (detik) \\
\hline 1 & 1 user & 2 \\
\hline 2 & 4 user & 3 \\
\hline 3 & 8 user & 5 \\
\hline 4 & 10 user & 5 \\
\hline
\end{tabular}

Pengujian berikutnya adalah pada sistem pengisian KRS lama berbasis WEB. Dari pengujian diperoleh data berikut.

Tabel 2 Hasil uji coba KRS lama berbasis web

\begin{tabular}{|c|c|c|}
\hline No & Jumlah User & Waktu rata-rata (detik) \\
\hline 1 & 1 user & 2 \\
\hline 2 & 4 user & 3 \\
\hline 3 & 8 user & 5 \\
\hline 4 & 10 user & 6 \\
\hline
\end{tabular}

Sebagai perbandingan lagi dilakukan pengujian pengisian KRS dengan menggunakan sistem yang telah diterapkan berbasis desktop. Waktu yang diperoleh adalah waktu untuk pengisian KRS untuk setiap satu matakuliah. Hasil dari pengujian sistem lama terdapat pada tabel 3.

Tabel 3 Hasil uji coba KRS lama berbasis desktop

\begin{tabular}{|c|c|c|}
\hline No & Jumlah User & $\begin{array}{c}\text { Waktu rata-rata (detik) tiap satu } \\
\text { matakuliah }\end{array}$ \\
\hline 1 & 1 user & 6 \\
\hline 2 & 4 user & 8 \\
\hline 3 & $8 u$ ser & 15 \\
\hline 4 & 10 user & 17 \\
\hline
\end{tabular}

\section{Uji Coba Sinkronisasi Pada LAN}

Pada pengujian ini proses sinkronisasi dilakukan pada jaringan LAN. Dari hasil pengujian diperoleh data yang dijelaskan pada tabel 4 .

Tabel 4 Hasil Uji Coba sinkronisasi Data pada LAN

\begin{tabular}{|c|c|c|}
\hline No & Record temporary server & Waktu (detik) \\
\hline 1 & 10 & 1 \\
\hline 2 & 50 & 1 \\
\hline 3 & 100 & 2 \\
\hline 4 & 150 & 3 \\
\hline
\end{tabular}




\section{Uji Coba Sikronisasi Pada Jaringan Internet}

Pada pengujian ini proses sinkronisasi dilakukan pada jaringan Internet. Tes pengujian ini digunakan untuk mengetahui tingkat keberhasilan dan keakuratan dalam mentrasfer data dari temporary server ke server utama, serta untuk mengetahui tingkat kecepatan dalam mentrasfer data. Sebagai uji coba dilakukan proses sinkronisasi data dengan memanfaatkan jasa web hosting menggunakan modem dengan kecepatan 512kbps. Kecepatan dalam transfer data tergantung dari jumlah record di server utama, dan jumlah data yang akan di transfer. Dari hasil pengujian diperoleh pada tabel 5.

Tabel 5 Hasil Uji Coba Transfer Data pada Jaringan Internet

\begin{tabular}{|l|c|c|}
\hline No & Record temporary server & Waktu (detik) \\
\hline 1 & 10 & 6 \\
\hline 2 & 50 & 9 \\
\hline 3 & 100 & 13 \\
\hline 4 & 150 & 15 \\
\hline
\end{tabular}

\section{Pembahasan Sistem Pengisian KRS}

Dari hasil uji coba diperoleh data kisaran waktu yang dibutuhkan untuk proses pengisian KRS dengan load balancing diperoleh waktu rata-rata 4.52 detik. Rata-rata waktu tersebut lebih cepat dibanding waktu yang diperlukan oleh sistem lama berbasis WEB yang membutuhkan waktu rata-rata 4.96 detik, dan 14.26 detik untuk pengisian KRS berbasis deskto. Data hasil uji coba menunjukan sistem pengisian KRS dengan load balancing lebih cepat baik dalam jumlah sedikit akses, maupun akses yang lebih banyak.

Perbandingan sistem pengisian KRS load balancing dengan sistem pengisian KRS (portal akademik) berbasis desktop adalah :

1. Dalam hal kecepatan sistem pengisian KRS dengan load balancing memiliki kecepatan yang lebih baik daripada pengisian KRS oleh portal akademik.

2. Sistem pengisian KRS berbasis load balancing belum memiliki fitur yang sebaik portal akademik seperti cek hasil studi, cek jadwal dan absensi.

3. Sistem pengisian KRS dengan load balancing dapat diakses pada jaringan lebih luas melalui browser karena berbasis WEB, sedangkan portal akademik hanya dapat diakses pada PC yang sudah ter-install aplikasi portal akademik.

4. Portal akademik memberikan keamanan yang lebih baik dibandingkan sistem pengisian KRS dengan load balancing yang berbasis WEB.

Perbandingan sistem pengisian KRS dengan load balancing dengan sistem pengisian KRS lama berbasis WEB adalah :

1. Kecepatan akses cepat pada jumlah user sedikit, sedangkan pada jumlah akses banyak sistem pengisia KRS dengan load balancing memberikan kecepatan lebih baik.

2. Sistem lama memiliki fitur yang lebih baik seperti cek transkip nilai, cetak KRS, ubah password login.

\section{Pembahasan Sinkronisasi Database}

Hasil Uji coba sinkronisasi data antara server utama dan temporary server dengan jumlah record temporary server sebanyak 150 record pada LAN membutuhkan waktu 6 detik, sedangkan pada jaringan internet membutuhkan waktu 15 detik. Waktu yang dibutuhkan untuk proses sinkronisasi dipengaruhi jumlah record, hal tersebut ditunjukan dengan 
peningkatan waktu proses yang berbanding lurus dengan jumlah record. Semakin banyak jumlah record database semakin banyak waktu yang diperlukan. Kecepatan eksekusi program pada jaringan internet juga dipengaruhi oleh kecepatan akses internet.

\section{Kesimpulan}

1. Sistem pengisian KRS dengan load balancing dapat meningkatkan kecepatan dalam menangani setiap request. Hal tersebut berdasarkan hasil percobaan dimana diperoleh rata-rata 4.52 detik. Rata-rata waktu tersebut lebih cepat dibanding sistem lama berbasis WEB yang membutuhkan waktu rata-rata 4.96 detik, dan 14.26 detik untuk pengisian KRS berbasis desktop.

2. Waktu yang dibutuhkan untuk proses sinkronisasi dipengaruhi oleh jumlah record database dan kecepatan transfer pada jaringan. Hal tersebut berdasarkan hasil percobaan dimana diperoleh peningkatan waktu eksekusi rata-rata 0.24 detik setiap penambahan 50 record.

3. Sistem ini menggunakan sinkronisasi yang diproses manual oleh seorang admin. Sinkronisasi dilakukan setelah masa pengisian KRS berakhir dan setelah masa revisi KRS berakhir.

\section{Saran}

1. Proses sinkronisasi dapat dikembangkan menjadi sinkronisasi otomatis. Pemanfaatan crontab pada sistem operasi linux bisa menjadi solusinya.

2. Pengembangan lebih lanjut adalah server utama tidak menggunakan temporary server melainkan server lain yang memiliki service yang sepenuhnya sama dengan server utama dengan teknik sinkronisasi yang lebih cepat sehingga dapat memberikan layanan tidak hanya pengisian KRS.

\section{Daftar Pustaka}

Bourke, Tony, 2011." Server Load Balancing", O'Reilly \& Associates, Inc., Sebastopol.

Ema, Utami, 2006." RDBMS dengan PostgreSQL di GNU/Linux", Penerbit Andi, Yogyakarta.

Hewlett-Packard Development Company, L.P, 2012." Load Balancing Technology White Paper".

Indrajit, Eko, 2002."Buku Pintar Linux: Database Server PostgreSQL", PT. Elex Media Komputindo, Jakarta.

Suprianto, Dodit, 2009." Buku Pintar Pemrograman PHP", OASE Media, Bandung.

Anonim, 2009, Pengertian Load Balancing http.//allnetedu.blogspot.com/2009/03/pengertian-loadbalancing.html, pada tanggal 23 April 2012, pukul 21.03 wib

Anonim, 2011, Load Balancing

http://imamnet.files.wordpress.com/2011/01/makalah-load-balancing.pdf pada tanggal 23 April 2012, pukul $21.03 \mathrm{wib}$

Anonim, 2011, Load Balancing

http://sisteminformasi.files.wordpress.com/2007/02/load-balancing.doc, pada tanggal 23 april 2012, pukul 21.03 wib 
Anonim, 2011, Virtual Server

http://sisteminformasi.files.wordpress.com/2007/02/virtual-server.doc, pada tanggal 23 april 2012, pukul 21.03 wib

Anonim, 2011, Sinkronisasi

http://puancek.blogspot.com/2011/04/metode-transmisi-asinkron-dan-sinkron.html, pada tanggal 23 april 2012, pukul 21.03 wib

Microsoft, 2012, Network Load Balancing Technical Overview

http:/ / technet.microsoft.com/en-us/library/bb742455.aspx, pada tanggal 1 agustus 2012, pukul $20.00 \mathrm{wib}$

keywords: Server, load balancing, sinkronisasi, postgre 